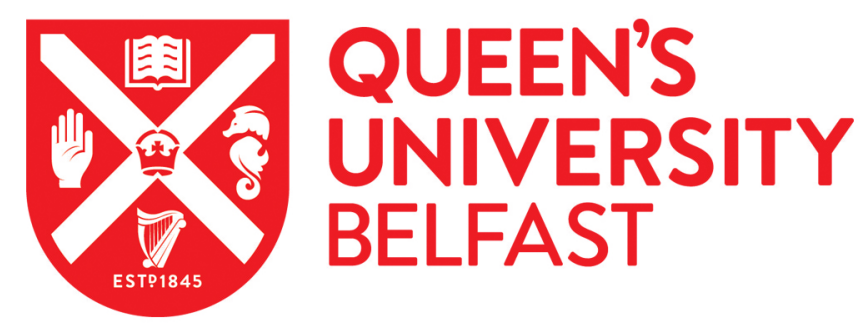

\title{
A comparison of sampling methods for seawater microplastics and a first report of the microplastic litter in coastal waters of Ascension and Falkland Islands
}

Green, D. S., Kregting, L., Boots, B., Blockley, D. J., Brickle, P., da Costa, M., \& Crowley, Q. (2018). A

comparison of sampling methods for seawater microplastics and a first report of the microplastic litter in coastal waters of Ascension and Falkland Islands. Marine Pollution Bulletin, 137, 695-701.

https://doi.org/10.1016/j.marpolbul.2018.11.004

\section{Published in:}

Marine Pollution Bulletin

\section{Document Version:}

Peer reviewed version

Queen's University Belfast - Research Portal:

Link to publication record in Queen's University Belfast Research Portal

\section{Publisher rights}

Copyright 2018 Elsevier.

This manuscript is distributed under a Creative Commons Attribution-NonCommercial-NoDerivs License

(https://creativecommons.org/licenses/by-nc-nd/4.0/), which permits distribution and reproduction for non-commercial purposes, provided the author and source are cited.

\section{General rights}

Copyright for the publications made accessible via the Queen's University Belfast Research Portal is retained by the author(s) and / or other copyright owners and it is a condition of accessing these publications that users recognise and abide by the legal requirements associated with these rights.

Take down policy

The Research Portal is Queen's institutional repository that provides access to Queen's research output. Every effort has been made to ensure that content in the Research Portal does not infringe any person's rights, or applicable UK laws. If you discover content in the

Research Portal that you believe breaches copyright or violates any law, please contact openaccess@qub.ac.uk. 
1 A comparison of sampling methods for seawater microplastics and a first report of the microplastic litter in coastal waters of Ascension and Falkland Islands

3

4 Dannielle S. Green ${ }^{1 *}$, Louise Kregting ${ }^{2}$, Bas Boots ${ }^{1}$, David J. Blockley ${ }^{3}$, Paul Brickle ${ }^{3,4}$, $5 \quad$ Marushka da Costa ${ }^{5}$, Quentin Crowley ${ }^{5}$

6

$7{ }^{1}$ Department of Biology, Anglia Ruskin University, Cambridge Campus, East Road, 8 Cambridge, Cambridgeshire, CB1 1PT, United Kingdom

$9{ }^{2}$ School of Natural and Built Environment, Queen's University Marine Laboratory, 12-13 The 10 Strand, Portaferry, BT22 IPF, Northern Ireland, UK

$11{ }^{3}$ South Atlantic Environmental Research Institute, Stanley Cottage, Ross Road, Stanley, $12 \quad$ Falkland Islands, FIQQ $1 Z Z$

${ }^{4}$ School of Biological Sciences (Zoology), University of Aberdeen, Tillydrone Avenue, Aberdeen, Scotland, AB24 2TZ, UK

${ }^{5}$ Trinity College Dublin

16

$17 *$ Corresponding author at:

*Department of Biology, Anglia Ruskin University, Science Centre, Cambridge,

Cambridgeshire, CB1 1PT, United Kingdom

Email: danniellesgreen@gmail.com 


\section{Abstract}

27 To date there is no gold standard for sampling microplastics. Zooplankton sampling methods, such as plankton and Neuston nets, are commonly used to estimate the concentrations of microplastics in seawater, but their ability to detect microplastics is limited by their mesh size. We compared different net-based sampling methods with different mesh sizes including bongo nets $(>500 \mu \mathrm{m})$, manta nets $(>300 \mu \mathrm{m})$ and plankton nets $(>200 \mu \mathrm{m}$ and $>400 \mu \mathrm{m})$ to 1 litre bottle grabbed, filtered $(0.45 \mu \mathrm{m})$ samples. Concentrations of microplastics estimated using net-based methods were $\sim 3$ orders of magnitude less than those estimated by 1 litre grab samples. Some parts of the world with low human populations, such as Ascension Island and the Falkland Islands, lack baseline data on microplastics. Using the bottle grab sampling method we found that microplastic litter was present at these remote locations and was comparable to levels of contamination in more populated coastal regions, such as the United Kingdom.

Keywords: grab samples, nets, anthropogenic litter, remote, Atlantic Ocean. 
Introduction

Microplastics (plastic particles $<5 \mathrm{~mm}$ in size) have become the most ubiquitous type of anthropogenic litter contaminating marine habitats worldwide, and due to the increasing production and mismanagement of single-use plastic items and the fragmentation of macroplastic litter, their prevalence is increasing (Jambeck et al. 2015). They can be 'primary', directly produced as micro-sized beads or fragments for use as exfoliants in a range of e.g. personal care products or they can be 'secondary', resulting from the fragmentation of larger plastic items e.g. bags, fishing gear and persist as fragments, films or fibres.

The majority of methods used for quantifying microplastics in marine environmental samples use zooplankton sampling methods with an average mesh size of $\sim 330 \mu \mathrm{m}$ (Barrows et al. 2017). Although these net-based methods have allowed highlighting hotspots of accumulation, the lower limits (based on their aperture) of nets are possibly leading to an underestimation in global concentrations of microplastics. Responding to this concern, Barrows et al. (2017) compared (1 L) grab samples with $335 \mu \mathrm{m}$ Neuston net tows and found that the grab samples collected over three orders of magnitude more microplastic particles per volume of seawater. This indicates that zooplankton sampling methods do indeed underestimate the environmental concentrations of relatively smaller microplastic particles $(<335 \mu \mathrm{m})$ and that further comparison of other commonly employed methods of sampling is required.

Although there has been extensive monitoring of microplastic contamination of the open oceans (Moore, 2008; Law et al., 2014), microplastics are likely to be more abundant in and around coastal areas (Browne et al. 2010; Wright et al. 2013; Zhao et al. 2014). Microplastics are an issue in coastal habitats as they can be ingested by a wide range of organisms. Effects on the health of individual organisms is well documented from laboratory experiments (for review see: Lusher et al. 2017, Wright et al. 2013). In addition, recent evidence suggests that at high concentrations $\left(\sim 1000\right.$ particles $\mathrm{L}^{-1}$ which is around 2 orders of magnitude greater than 
currently reported environmental levels), microplastic contamination in coastal water columns may also settle or be deposited onto shallow water benthic habitats and can alter faunal and floral communities and reduce primary productivity (Green 2016, Green et al. 2017). It is, therefore, vital to monitor the levels of contamination in coastal habitats in order to prevent these areas from reaching critical levels for negative impacts to occur (Gago et al. 2016).

Although it seems intuitive that greater levels of contamination will occur in locations close to large coastal populations of humans, such as the Mediterranean (1 to 10 particles $\mathrm{m}^{-2}$ using a $200 \mu \mathrm{m}$ neuston net, Cózar et al. 2015), the East Asian sea (surface waters sampled with a 350 $\mu$ m plankton net had an average ( \pm S.D.) of $3.7 \pm 10.4$ particles $\mathrm{m}^{-3}$, Isobe et al. 2015$)$ and the south-eastern coast of Korea ( $\sim 7$ particles $\mathrm{L}^{-1}$ when using a net with $50 \mu \mathrm{m}$ mesh size, Kang et al., 2015), there is also evidence that relatively remote areas with sparse human populations are also contaminated with microplastic litter, for example, coastal sediments of marine protected areas in the Balearic Islands were more contaminated with microplastics than more urbanised areas (>800 particles $\mathrm{kg}^{-1}$ dry sediment, Alomar et al., 2016), trapped in Arctic Sea ice (up to 234 particles $\mathrm{m}^{-3}$ of ice, Obbard et al. 2014) and in surface \& subsurface waters of the Arctic Sea (0 to 1.31 particles $\mathrm{m}^{-3}$ using a $333 \mu \mathrm{m}$ manta net, Lusher et al. 2015). Plankton net trawls from surface waters of the Southern Ocean between Australia and Antarctica also found microplastics of $3.1 \times 10^{-2} \mathrm{~m}^{-3} 100,000$ pieces $\mathrm{km}^{-2}$, mainly consisting of fibres (Isobe et al. 2017). Different sampling methods inevitably lead to a range of different units of concentration being used, which if not able to be converted, can make it difficult to make comparisons. Standardisation of analytical protocols for quantifying microplastics would help solve this issue (Mai et al. 2018).

For some parts of the world, however, there is very little or no baseline information on microplastic concentrations. For example, Ascension Island and the Falkland Islands have no data on their coastal microplastic litter. Data on the abundance and distribution of stranded 
90 (Otley and Ingham, 2003) and floating (Barnes and Milner, 2005) macroplastic debris in these areas suggest that, perhaps due to the fragmentation of these larger items, microplastic litter may also be prevalent and therefore it is important to monitor this.

In order to quantify the level of under-estimation of microplastic concentrations obtained by current common methods of microplastic sampling in seawater, we compared the abundances of microplastics recorded by three common sampling methods (bongo, manta and plankton nets) with those obtained by of $1 \mathrm{~L}$ filtered seawater obtained with bottle grabs. Furthermore, we used bottle grab sampling to quantify the abundance of microplastic litter around the coastal surface waters of Ascension Island and the Falkland Islands and compared it to abundances found in more densely populated regions of the world.

\section{Materials and Methods}

\subsection{Prevention and quantification of airborne contamination}

Inadvertent contamination from the air or from the synthetic clothing of researchers is a common problem thought to lead to an over-estimation of microplastic fibres in environmental samples (Wesch et al. 2017). In order to prevent contamination of samples from their own clothing, researchers wore tightly woven cotton jackets instead of synthetic fleeces whilst sampling and white, cotton laboratory coats during sorting in the laboratory. Glass sample bottles ( $1 \mathrm{~L}$, metal caps) were thoroughly rinsed (three times with tap water followed by three times with ultra-pure water) and checked for contamination by filling with pre-filtered $(0.45$ $\mu \mathrm{m}$ aperture) water and processing this filtered water using the same method as for the environmental samples. All equipment used was rinsed with ultra-pure or deionised water before covering with clean tinfoil. All bench tops and microscopes were cleaned prior analysis of the filtered samples. In order to quantify levels of potential contamination with airborne microplastics during filtration, pre-filtered water was passed through a clean GF/C filter paper 
to check for contamination of the filtering apparatus. Filtered samples were placed immediately into covered Petri dishes while the time exposed to open air was less than 5 seconds. No contamination was found in the filtering apparatus nor in the glass bottles. In addition, to quantify airborne contamination in the laboratory during sample processing, 3 moist filter papers were placed in Petri dishes and exposed to the air within the fume hood and on the laboratory benches during each instance of sample processing.

\subsection{Sampling using common zooplankton methods versus one litre grab samples.}

In the Summer of 2015 at three different locations; Stanley Harbour in the Falkland Islands (51'41'20.4”S; 5750'55.3”W), Plymouth Sound in England, UK (50²0'57.3”N; $4^{\circ} 08^{\prime} 41.8^{\prime \prime} \mathrm{W}$ ) and Strangford Narrows in Strangford Lough, Northern Ireland, UK $\left(54^{\circ} 25^{\prime} 28.4^{\prime \prime} \mathrm{N} ; 5^{\circ} 35^{\prime} 49.8^{\prime} \mathrm{W}\right)$, one or two commonly used zooplankton net sampling techniques were compared with bulk sampling using one litre bottles. The methods used at each site were selected based on what sampling equipment was available at that location. These three sampling events were treated as separate surveys and, as such, are presented and analysed separately (Table 1). All samples were processed by the same person to reduce analyst bias when comparing sampling methods.

Table 1. Summary of sampling methods compared and the location in which they occurred.

\begin{tabular}{ll}
\hline Location & Methods compared \\
\hline Stanley Harbour & Bongo net vs bottle grab \\
Plymouth Harbour & Manta net vs bottle grab \\
Strangford Lough & Plankton nets (one coarse and one fine) versus bottle grab \\
\hline
\end{tabular}

\subsubsection{East Falklands; bottle versus bongo nets $(500 \mu \mathrm{m})$}

136 Bongo nets with $500 \mu \mathrm{m}$ mesh and a diameter of $30 \mathrm{~cm}$ were deployed off the back of a vessel 137 and towed for exactly 5 minutes at 5 knots, maintained at a depth of $1 \mathrm{~m}$ in Stanley Harbour. 

in the mouths of the nets allowed the volume of water that passed through to be calculated accurately, resulting in $\sim 30 \mathrm{~m}^{3}$ of water sampled each time. On deck, after towing, the contents of the cod end was rinsed out using distilled, filtered water, into $500 \mathrm{ml}$ glass sample jars. During the tow, in between each bongo net sample, seawater samples from the sub-surface $(\sim 50 \mathrm{~cm})$ of the water were collected by hand in one litre glass bottles from the back of the vessel. These samples were capped whilst still being held under water in order to avoid airborne contamination. In the laboratory, water samples were filtered through $0.45 \mu \mathrm{m}$ glass fibre filters (GF/F) and were visually sorted under a dissecting microscope. Particles that appeared to be plastic, according to criteria suggested by Hidalgo-Ruz et al. (2012), were then recorded and classified as either 'fibres', 'films', 'fragments' or 'beads'. Although visual identification of microplastics is prone to error (either under- or over- estimating the abundance of microplastics; Song et al. 2015), training and experience is likely to lower the error rates of visual identification (Lusher et al. 2017) and in the current study an experienced researcher undertook all visual sorting and a subset of microplastics were confirmed using FT-IR analysis (see section 2.3). Filters were placed in clean, lidded, glass petri dishes and, once dry, were observed under a dissecting microscope (magnification $\mathrm{x}$ 40) in a systematic manner using a longitudinal top to bottom traverse method starting from top left hand corner and a $1 \mathrm{~cm}^{2}$ grid drawn onto the petri dish. A total of six samples were collected for each method $(\mathrm{N}=12)$.

\subsubsection{Plymouth Sound; bottle versus Manta (300 $\mu \mathrm{m})$}

A manta net with a rectangular opening $50 \mathrm{~cm}$ wide $\mathrm{x} 15 \mathrm{~cm}$ deep lined with a $3 \mathrm{~m}$ long 300 $\mu \mathrm{m}$ net fitted with a $30 \times 10 \mathrm{~cm}^{2}$ screw-fit collecting bag was used to sample the surface layer (top $15 \mathrm{~cm}$ ) of the water in Plymouth Sound. Plymouth Sound is a bay on the English Channel at Plymouth in England. The manta was fixed onto a frame and was trawled alongside the 
vessel for 5 minutes at 5 knots. Material caught in the cod end of the net was rinsed into 500 $\mathrm{mL}$ glass sample jars which was filtered onto cellulose filter paper (retention of $11 \mu \mathrm{m}$ ) and visually sorted under a dissecting microscope in a laminar flow cupboard. This was compared with bottle grab samples collected and processed as detailed previously in section 2.2.1 and were also processed within the laminar flow cupboard. A total of ten samples were collected for each method $(\mathrm{N}=20)$. Appropriate controls were included throughout as described in section 2.1 and no airborne contamination was observed.

\subsubsection{Strangford Narrows; bottle versus $200 \mu \mathrm{m}$ and $400 \mu \mathrm{m}$ plankton nets}

To compare plankton nets (with a diameter of $50 \mathrm{~cm}$ ) of two mesh sizes $(200 \mu \mathrm{m}$ or $400 \mu \mathrm{m})$ with samples collected in bottles of 1 litre, the survey was conducted in the Strangford Narrows, Strangford Lough, a fast flow channel. Strangford Lough on the Island of Ireland is connected to the Irish Sea located between the two landmasses of the UK and Ireland. Plankton nets were deployed off the side of a moored barge during flood tide at the location for exactly 5 minutes. In order to monitor flow velocity a Nortek Aquadopp $2 \mathrm{MHz}$ (Acoustic Doppler Current Profiler) was mounted alongside the nets at $2 \mathrm{~m}$ below the barge to calculate the volume using average velocities at the depth of the nets. After each tow the cod ends were rinsed with distilled, filtered water, into $500 \mathrm{~mL}$ glass sample jars and a bottle sample was taken. Samples were processed as described in 2.2.2. A total of seven samples were collected for each method $(\mathrm{N}=21)$ at this location.

The volume $V\left(\mathrm{~m}^{3}\right)$ of water sampled for each net method (bongo, manta and plankton) was estimated using the net entrance surface area $A\left(\mathrm{~m}^{2}\right)$ and the length of the tow:

$$
V=A * L
$$



Falklands

In August 2015, surveys for microplastic litter were done at 6 sites on Ascension Island and at 11 sites on the Falkland Islands (East Falklands only). At each site, 5 seawater samples were taken from the surface (top $\sim 5 \mathrm{~cm}$ ) of the water in one litre glass bottles, giving a total of 85 samples (30 at Ascension Island and 55 at the Falkland Islands). Glass bottle samples were collected and processed as detailed in 2.2.1.

\subsection{Characterisation of polymers from microplastic particles}

A Perkin Elmer 200i Spotlight Microscope FT-IR spectrometer was used to characterise the polymers of microplastics from a randomly selected subset (10\%) of the samples. To maximise the resolution of the readings microplastics were first subjected to $30 \%(\mathrm{v} / \mathrm{v})$ solution of $\mathrm{H}_{2} \mathrm{O}_{2}$ overnight to avoid any interference from biological material and were then directly mounted onto the crystal surface of the FTIR.

\subsection{Statistical data analysis}

204

For statistical analysis, the concentrations of microplastics obtained from each sampling method were converted to number of particles per litre. The data did not conform to parametric assumptions of normality and homogeneity of variance, therefore non-parametric tests (Wilcoxon rank sum tests) were used to compare the bottle versus bongo nets and the bottle versus manta net methods. Similarly, Kruskal-Wallis rank sum tests with Wilcoxon tests for pairwise comparisons were used to compare the bottle versus coarse or fine plankton nets and also to compare the concentrations of microplastics found with the bottle method amongst the four locations (Ascension Island, the Falkland Islands, Plymouth Sound and Portaferry). 
212 Statistical significance were assumed at $\alpha=0.05$. All statistical analyses were done using the

213 R environment ( $\mathrm{R}$ v3.1.3; $\mathrm{R}$ core team 2015).

\section{Results}

\subsection{Sampling using one litre bottles versus common zooplankton methods}

In each of the three locations, the bottle grab method yielded between 3 and 4 orders of magnitude greater abundances of total microplastic particles $\mathrm{L}^{-1}$ and these differences were statistically significant in all three surveys (Table 2), but varied depending on the type of microplastic.

In the Falkland Islands, the number of microplastic films did not significantly differ between sampling methods $(\mathrm{P}=0.774)$, however the number of microplastic fragments found was greater $(\mathrm{P}=0.028)$ when using Bongo nets than when using the bottle grab method. On the contrary, the number of fibres was significantly greater $(\mathrm{P}=0.005)$ in samples collected using the bottle method than by using Bongo nets (Table 2). In Plymouth Sound, there were no microplastic films found using either method and there was no significant difference between the number of microplastic fragments found using the Manta net compared with the bottle method $(\mathrm{P}=0.455)$. On the contrary, the average number of fibres found was significantly greater when using the bottle method compared with the Manta net $(\mathrm{P}=<0.001)$. In addition, a total of 17 meso-plastics (> $5 \mathrm{~mm}$ ) were found using the Manta net, representing an average of $1.09 \times 10^{-4}\left(\mathrm{SE}=6.63 \times 10^{-5}\right) \mathrm{L}^{-1}$. It is worth noting that no meso-plastics were found in bottle grab samples and analysis was only done to compare the abundance of microplastics $(<5$ $\mathrm{mm}$ ). Finally, in Strangford Narrows, the average number of microplastic films was significantly greater when using a fine plankton net than when using a coarse plankton net or the bottle method $(\mathrm{P}=0.027)$. There were no significant differences in the number of microplastic fragments amongst the methods $(\mathrm{P}=0.810)$, but the number of microplastic fibres 
found was significantly greater when using the bottle method or the fine plankton net than when using the coarse plankton net $(\mathrm{P}=0.002$; Table 2).

From the three surveys to compare methods, a subset of 11 samples (29 microplastic particles) were identified and confirmed with FTIR spectrometry. From the Falkland Islands, 4 out of a possible 12 replicate samples (6 individual microplastics) were identified, from these; 3 were polyethylene, 1 was monocrystalline cellulose, 1 was regenerated cellulose and 1 was undetermined polyamide (nylon). In Plymouth, 3 out of 20 samples (14 microplastics) were identified, from these; 5 were polypropylene, 5 were polyethylene terephthalate and 4 were polyethylene. Finally, in Strangford Narrows, 4 out of 21 samples (9 microplastics) were identified, from these; 2 were acrylic, 2 were polypropylene, 2 were polyvinyl chloride, 1 was neoprene, 1 was polyethylene and 1 was polyvinyl acetate.

\subsection{Microplastic litter in coastal waters of Ascension Island and The Falkland Islands}

Microplastic litter was found at every site sampled around the coastal waters of Ascension Island (Figure 1) and the East Falklands (Figure 2), and concentrations ranged from 0.4 to 9 particles $\mathrm{L}^{-1}$. The majority (94\%) of microplastics collected were fibres, with films accounting for $\sim 5 \%$ and fragments representing only $<1 \%$ (Table 3). A subset of 11 out of 55 samples (15 microplastics) from the Falklands were further identified using FTIR analysis. Of these, 6 were polyethylene, 3 were polyethylene terephthalate and the following six polymers constituted 1 microplastic each; monocrystalline cellulose, nylon, polyester, polymethyl methacrylate, polystyrene and regenerated cellulose.

The concentrations of microplastics found using the bottle method significantly differed $(\mathrm{W}=$ 20.41, d.f. $=3, \mathrm{P}<0.001)$ amongst the four locations in this study, with the Falkland Islands having greater abundances of microplastics than Portaferry $(\mathrm{P}<0.001)$ or Plymouth $(\mathrm{P}=$ 0.0398), but not differing to Ascension Island $(\mathrm{P}=0.127)$. The concentration of microplastics 
found at Ascension Island also did not significantly differ to those found at Plymouth $(\mathrm{P}=$ 0.295) or Portaferry $(\mathrm{P}=0.097)$.

\section{Discussion}

This set of comparative studies indicates that three common zooplankton sampling methods (manta, bongo and plankton nets), frequently used to sample microplastics, may underestimate the concentrations of microplastic fibres by 3 to 4 orders of magnitude compared to when using the grab method. Other types of microplastic, however, such as fragments and films were underestimated in some cases by the grab method when compared with Bongo nets or a fine $(200 \mu \mathrm{m})$ plankton net.

Estimating and monitoring the concentrations of microplastics is vital for understanding the current and future implications of microplastic litter for marine ecosystems worldwide (as recommended by national and international policies, and legislation such as the EU Marine Strategy Framework Directive (2008/56/EC) and the NOAA Marine Debris Programme). The desired method of choice may depend upon the context and aims of the sampling regime, for example, if the aim of the sampling regime is to capture and sort meso- and larger microplastics in-situ without a microscope, zooplankton tow methods will yield better results because they sample a larger volume of water and therefore increase the potential to capture these pieces. Due to the small filter pore size $(0.45-11 \mu \mathrm{m})$, the grab method is more likely to capture smaller pieces of microplastics which zooplankton nets $(>200 \mu \mathrm{m})$ will miss, however, the small volume of water sampled may omit larger micro- and meso- plastics (> $5 \mathrm{~mm})$. On the other hand, the need to measure flow speeds in order to estimate the volume of water processed and the act of cleaning the net in between each tow is likely to introduce uncertainty into measurements taken using zooplankton methods. As recommended by Barrows et al. (2017) a 
combination of methods is likely to lead to a greater overall understanding of the concentrations

Coastal regions are vitally important economically (providing valuable ecosystem services; Costanza et al. 2014) and ecologically (supporting unique biodiversity; Ray, 1991, UNEP, 2006) and they provide habitat for over a third of the world's human population, and as such, are under pressure from a myriad of anthropogenic threats (including habitat loss, overfishing, invasive species, climate change, eutrophication and pollution). There is, therefore, a critical need to standardise sampling methods in order to allow environmental managers to accurately track levels of contamination and to prioritise areas most at risk from microplastic pollution. Due to the lack of no specialist equipment required and replicability of the grab method, it is a very promising approach to e.g. facilitate citizen science programmes aimed at monitoring microplastic concentrations at large spatial scales. Indeed, citizen science using the grab method has recently been utilised by Barrows et al. (2018) in a global assessment of microplastic litter in seawater samples and it was found that the samples contained an average of $11.8 \pm 24.0$ particles $\mathrm{L}^{-1}$ with an average of $13.4 \pm 0.9$ particles $\mathrm{L}^{-1}$ for the Atlantic Ocean, similar to the estimate for the coastal waters of the Falkland Islands of $9.8 \pm 1.5$ particles $\mathrm{L}^{-1}$ reported in the current study. There is evidence that the grab method is an appropriate way to monitor microplastic contamination that could be paired with existing environmental surveys with relatively little effort leading to a standardised monitoring protocol. Based on the current study it is recommend that this method be utilised, perhaps combined with a citizen science approach, thereby raising public awareness of microplastic pollution whilst also improving the reliability of datasets to record patterns of microplastic contamination over space and time.

This study found that the coastal waters of two remote islands with very small populations, and the East Falklands ( 3200 people in the 2016 census), are subject to similar (and even 
greater) levels of contamination of microplastics as coastlines with a greater human population density such as the United Kingdom ( 263,100 people in Plymouth and $\sim 100,000$ people in the towns surrounding Strangford Lough, Northern Ireland). This is not entirely surprising given recent discoveries of high levels of microplastic contamination in other remote locations such as Antarctica (Waller et al. 2017) and the Arctic (Lusher et al. 2015; Cózar et al. 2017). Identifying the source of microplastics is currently difficult and speculative, but some of the fibres found in this study had the appearance of weathered fragments of ropes or fishing nets (Figure 3). Other researchers have correlatively linked increasing microplastic debris to increasing numbers of fishing vessels (in the Arctic (Tekman et al. 2017) or to increasing mariculture activity (in the Xiangshan Bay in China (Chen et al. 2018). Production of fishery and aquaculture has increased approximately eightfold since 1950 with these food products accounting for $17 \%$ of animal protein intake by the world's population. The development and success of this industry has been largely due to plastic. Synthetic materials are stronger, more durable and weigh less than natural materials and, as such, are used in almost all elements of the industry including the construction of boats, ropes, fishing gear and seafood packaging (FAO, 2017). Although, at present, there are no current global estimates of the contribution of fisheries and aquaculture to microplastic litter in marine environments, it is a possibility since larger plastic items from fisheries and aquaculture regularly contaminate surface waters (Cózar et al., 2014; Thiel et al., 2003) or the seafloor (Iñiguez et al. 2016) that these could degrade into microplastics. In addition to potentially contributing to marine microplastic debris, there is concern for food safety of fisheries and aquaculture products due to contamination with microplastics and their associated toxins (Rochman et al., 2015; Wardrop et al., 2016). The Falkland Islands has a relatively large fishery with a total annual catch (last 5 years) of 270,000 tonnes (Falkland Islands Government, 2018) and given that contamination of important fisheries species with microplastics has been found in other parts of the Atlantic Ocean 

and abundance of microplastics in fisheries grounds.

In conclusion, there is a lack of data describing the spatial and temporal variability of the concentrations of microplastics and the impacts that they might have in remote locations such as Ascension Island and the Falklands. Future research should focus on implementing standardised routine monitoring of coastal waters (ideally using a grab bottle method), in order to more fully understand the extent of microplastics contamination.

\section{Acknowledgements}

Our appreciation extends to the South Atlantic Environmental Research Institute as well as a Queen's University Belfast fellowship awarded to LK for funding this research and to the Falkland Islands fisheries for allowing us to use their vessel and facilities, to Richard Ticehurst for assisting with fieldwork in Plymouth, Carwyn Frost and Ian Benson for assisting with sample collection from the mooring barge in the Strangford Narrows and to Ilaria Marengo and Megan Tierney for their assistance in the field in the Falklands and to SAERI's IMS-GIS Centre for the maps.

\section{Author contributions}

DSG conceived the ideas for the methods comparison. DJB conceived the idea for sampling

357 Ascension and Falklands. LK, BB, DJB, PB and DSG carried out the work. MC and QC carried out FTIR analysis. DSG wrote the paper and all authors helped with edits. All authors approve the final version of the manuscript. 
References

362

363

364

365

366

367

368

369

370

371

372

373

374

375

376

377

378

379

380

381

382

383

384

385

Alomar C, Estarellas F, Deudero S. 2016. Microplastics in the Mediterranean Sea: deposition in coastal shallow sediments, spatial variation and preferential grain size. Marine Environmental Research 115, 1-10.

Alves VE, Patrício J, Dolbeth M, Pessanha A, Palma AR, Dantas EW, Vendel AL. 2016. Do different degrees of human activity affect the diet of Brazilian silverside Atherinella brasiliensis? Journal of Fish Biology 89(2):1239-57.

Barnes DKA, Milner P. 2005. Drifting plastic and its consequences for sessile organism dispersal in the Atlantic Ocean. Marine Biology 146: 815.

Barrows APW, Courtney A, Neumann CA, Berger ML, Shawad SD. 2017. Grab vs. neuston tow net: a microplastic sampling performance comparison and possible advances in the field. Analytical Methods, 9: 1446-1453.

Barrows APW, Cathey SE, Petersen CW. 2018. Marine environment microfiber contamination: Global patterns and the diversity of microparticle origins. Environmental Pollution, 237, Pages 275-284.

Browne MA, Galloway TS, Thompson RC. 2010. Spatial patterns of plastic debris along estuarine shorelines. Environmental Science and Technology, 44: 3404-3409.

Chen M, Jin M, Tao P, Wang Z, Xie W, Yu X, Wang K. 2018. Assessment of microplastics derived from mariculture in Xiangshan Bay, China. Environmental Pollution, 242, 1146-1156. 
Collard F, Gilbert B, Eppe G, Parmentier E, Das K. 2015. Detection of Anthropogenic Particles in Fish Stomachs: An Isolation Method Adapted to Identification by Raman Spectroscopy. Archives of Environmental Contamination and Toxicology, 69: 331-339.

Costanza R, de Groot R, Sutton P, van der Ploeg S, Anderson SJ, Kubiszewski I, Farber S, Turner K. 2014. Changes in the global value of ecosystem services. Global Environmental Change, 26, Pages 152-158.

Cózar A, Sanz-Martín M, Martí E, González-Gordillo JI, Ubeda B, Gálvez JÁ, Irigoien X, Duarte CM. 2015. Plastic Accumulation in the Mediterranean Sea. PLoS ONE 10(4): $\mathrm{e} 0121762$.

Cózar A, Martí E, Duarte CM, García-de-Lomas J, Van Sebille E, Ballatore TJ, Eguíluz VM, González-Gordillo JI, Pedrotti ML, Echevarría L, Troublè R, Irigoien X. 2017. The Arctic Ocean as a dead end for floating plastics in the North Atlantic branch of the Thermohaline Circulation. Science Advances, 3: e1600582.

Falkland Islands Government. 2018. Fisheries Department Fisheries Statistics, Volume 22, 2017: 100pp. Stanley, FIG Fisheries Department.

Fox J, Weisberg S. 2011. An \{R $\}$ Companion to Applied Regression, Second Edition (Sage) p http://socserv.socsci.mcmaster.ca/jfox/Books/Companion.

Gago J, Galgani F, Maes T, Thompson RC. 2016. Microplastics in Seawater: Recommendations from the Marine Strategy Framework Directive Implementation Process. Frontiers in Marine Science, | https://doi.org/10.3389/fmars.2016.00219

Green DS, 2016. Effects of microplastics on European flat oysters, Ostrea edulis and their associated benthic communities. Environmental pollution, 216, pp.95-103. 
416 Green DS, Boots B, O'Connor NE, Thompson RC. 2017. Microplastics Affect the Ecological

417 Functioning of an Important Biogenic Habitat. Environmental Science \& Technology $418 \quad 51(1): 68-77$.

419

420 Hidalgo-Ruz V, Gutow L, Thompson RC, Thiel M. 2012. Microplastics in the Marine 421 Environment: A Review of the Methods Used for Identification and Quantification. 422 Environmental Science \& Technology, 46:3060-3075.

423

424

Iñiguez ME, Conesa JA, Fullana A. 2016. Marine debris occurrence and treatment: A review.

Renewable Sustainable Energy Reviews, 64: 394-402.

426

427 Isobe A, Uchida K, Tokai T, Iwasaki S. 2015. East Asian seas: A hot spot of pelagic 428 microplastics, Marine Pollution Bulletin, 101(2): 618-623.

429

430

Isobe A, Uchiyama-Matsumoto K, Uchida K, Tokai T. 2017. Microplastics in the Southern 431

Ocean. Marine Pollution Bulletin, 114, 623-626.

432

Jambeck JR, Geyer R, Wilcox C, Siegler TR, Perryman M, Andrady A, Narayan R, Lavender

Law K. 2015. Plastic waste inputs from land into the ocean. Science 347(6223):768-771.

435

436

Kang JH, Kwon OJ, Lee KW, Song YK, Shim WJ. 2015. Marine neustonic microplastics around the southeastern coast of Korea,Marine Pollution Bulletin, 96(1-2: 304-312.

Law KL, Moret-Ferguson SE, Goodwin DS, Zettler ER, De Force E, Kukulka T, Proskurowski 
Lusher AL, Hollman PCH, Mendoza-Hill JJ. 2017. Microplastics in fisheries and aquaculture: status of knowledge on their occurrence and implications for aquatic organisms and food safety. FAO Fisheries and Aquaculture Technical Paper. No. 615. Rome, Italy.

Lusher AL, Welden NA, Sobral P, Cole M. 2017. Sampling, isolating and identifying microplastics ingested by fish and invertebrates. Analytical Methods, 9(9): 1346-1360.

Lusher AL, Tirelli V, O'Connor I, Officer R. 2015. Microplastics in Arctic polar waters: the first reported values of particles in surface and sub-surface samples. Scientific Reports 5, 14947.

Lusher AL, Burke A, O’Connor I, Officer R. 2014. Microplastic pollution in the Northeast Atlantic Ocean: Validated and opportunistic sampling. Marine Pollution Bulletin, 88(1-2): 325-333.

Mai L, Bao LJ, Shi L, Wong CS, Zeng EY. 2018. A review of methods for measuring microplastics in aquatic environments. Environmental Science and Pollution Research, 25(12): 11319-11332.

Moore CJ. 2008. Synthetic polymers in the marine environment: a rapidly increasing, longterm threat. Environmental Research 108(2): 131-139.

Neves D, Sobral P, Ferreira JL, Pereira T. 2015. Ingestion of microplastics by commercial fish off the Portuguese coast, Marine Pollution Bulletin, 101(1): 119-126.

Obbard RW, Sadri S, Wong YQ, Khitun AA, Baker I, Thompson RC. 2014. Global warming releases microplastic legacy frozen in Arctic Sea ice. Earth's Future, 2: 315-320. 
Otley H, Ingham R. 2003. Marine debris surveys at Volunteer Beach, Falkland Islands, during the summer of 2001/02. Marine Pollution Bulletin, 46(12): 1534-1539.

Ray GC. 1991. Coastal-Zone Biodiversity Patterns. BioScience. 41(7): Marine Biological Diversity, pp. 490-498.

Rochman CM, Tahir A, Williams SL, Baxa DV, Lam R, Miller JT, Teh FC, Werorilangi S, Teh SJ. 2015. Anthropogenic debris in seafood: Plastic debris and fibers from textiles in fish and bivalves sold for human consumption. Scientific Reports 5: 14340.

Song YK, Hong SH, Jang M, Han GM, Rani M, Lee J, Shim WJ. 2015. A comparison of microscopic and spectroscopic identification methods for analysis of microplastics in environmental samples. Marine Pollution Bulletin, 93(1-2): 202-209.

Tekman MB, Krumpen T, Bergmann M. 2017. Marine litter on deep Arctic seafloor continues to increase and spreads to the North at the HAUSGARTEN observatory, Deep Sea Research Part I: Oceanographic Research Papers, 120: Pages 88-99,

Thiel M, Hinojosa I, Vásquez N, Macaya E. 2003. Floating marine debris in coastal waters of the SE-Pacific (Chile). Marine Pollution Bulletin 46(2): 224-231.

United Nations Environment Programme (UNEP). 2006. Marine and coastal ecosystems and human wellbeing: A synthesis report based on the findings of the Millennium Ecosystem Assessment. UNEP. 76pp

Waller CL, Griffiths HJ, Waluda CM, Thorpe SE, Loaizac I, Morenoc B, Pacherresc CO, Hughes KA. 2017. Microplastics in the Antarctic marine system: an emerging area of research. Science of the Total Environment, 598: 220-227.

Wardrop P, Shimeta J, Nugegoda D, Morrison PD, Miranda A, Tang M, Clarke BO. 2016. Chemical pollutants sorbed to ingested microbeads from personal care products accumulate in fish. Environmental Science \& Technology 50(7): 4037-4044. 
503 Wesch C, Elert AM, Wörner M, Braun U, Klein R, Paulus M. 2017. Assuring quality in 504 microplastic monitoring: About the value of clean-air devices as essentials for verified data. 505 Scientific Reports 7: 5424.

506

507 Wright SL, Thompson RC, Galloway TS. 2013. The physical impacts of microplastics on 508 marine organisms: A review. Environmental Pollution, 178, 483-492.

509

510 Zhao SY, Zhu LX, Wang T, Li DJ. 2014. Suspended microplastics in the surface water of the 511 Yangtze estuary system, China: first observations on occurrence, distribution. Marine Pollution 512 Bulletin, 86: 562-568. 


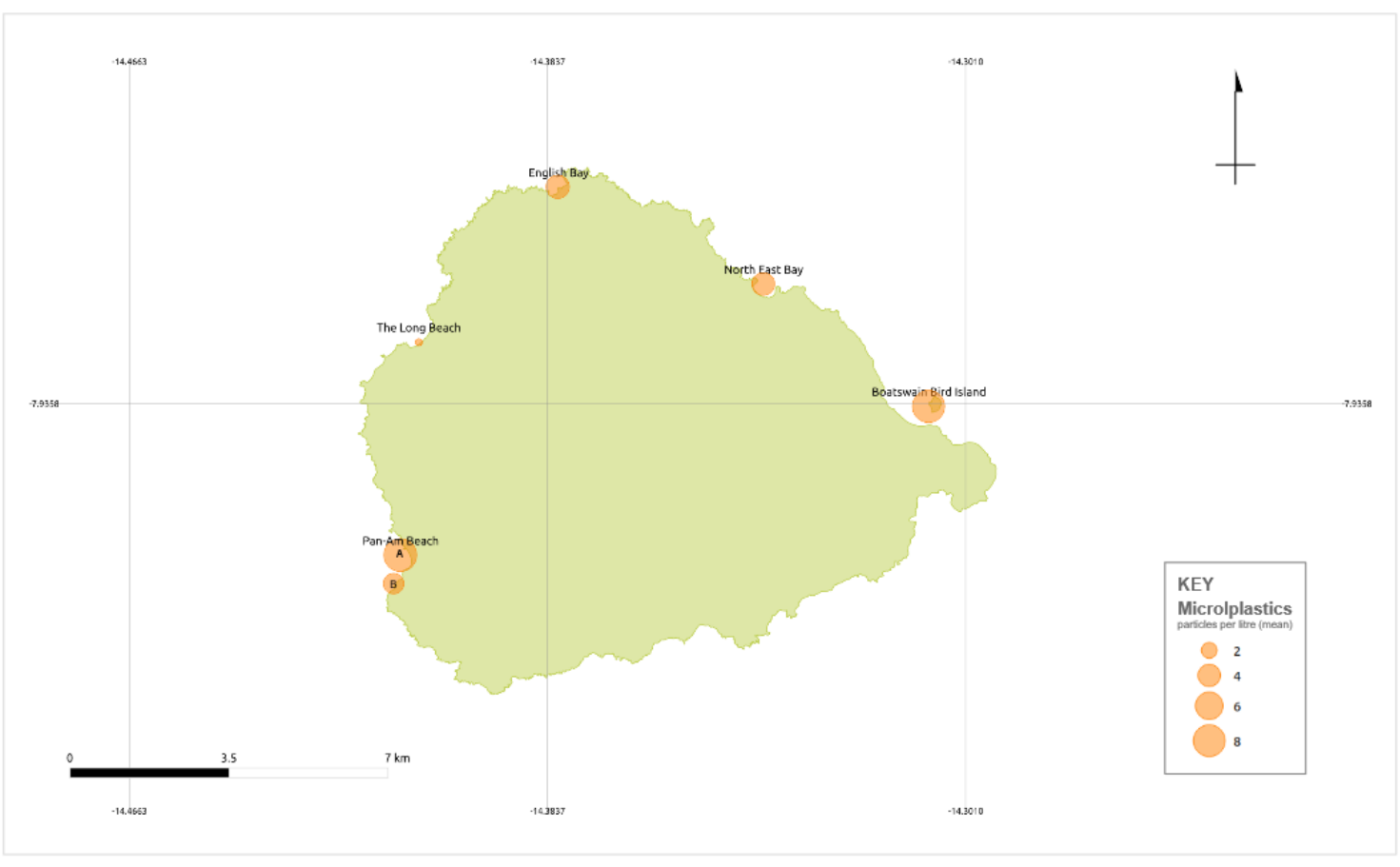

514

515 Figure 1. Map of Ascension Island showing average concentrations of microplastics (particles

$\mathrm{L}^{-1}$ ) obtained with $1 \mathrm{~L}$ bottle grab sampling.

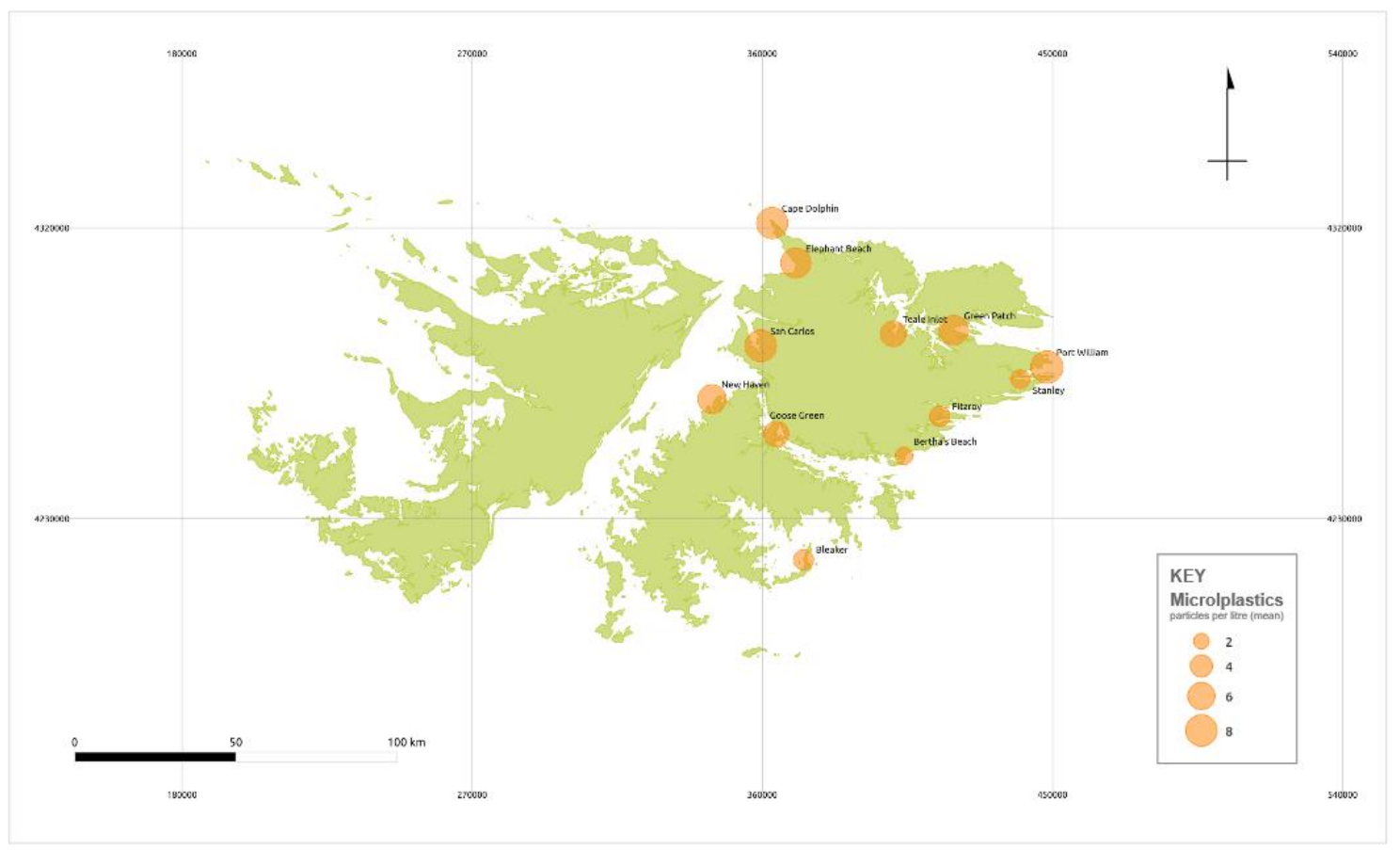

518 Figure 2. Map of the Falkland Islands showing average concentrations of microplastics 519 (particles $\mathrm{L}^{-1}$ ) in the East Falklands obtained with 1L bottle grab sampling. 

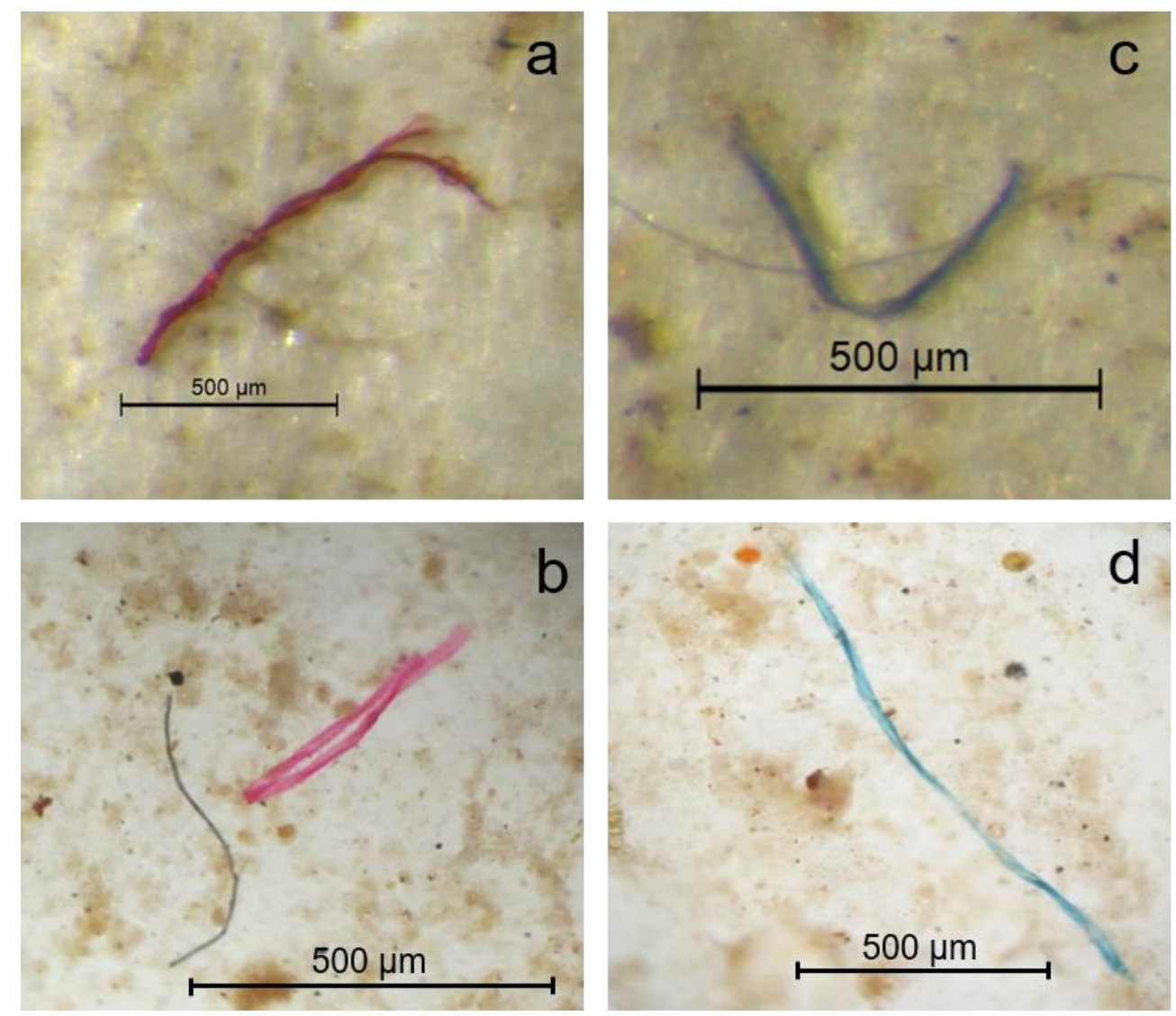

520

521 Figure 3. Photographs of microplastic fibres found in Ascension Island (a, b) or the East

522 Falklands (c, d). 
Table 1. Median (+ Inter Quartile Range (IQR)) number $\mathrm{L}^{-1}$ of microplastic films, fragments, fibres and total microplastics determined using different sampling methods including bulk one litre samples (Bottle) versus towing bongo nets (Bongo), Manta nets (Manta) or Plankton nets with either a $400 \mu \mathrm{m}$ (Coarse) or a $200 \mu \mathrm{m}$ (Fine) mesh. Results of non-parametric statistical analyses Wilcoxon rank sum test (W) with d.f. $=5$ for Falklands and 9 for Plymouth and Kruskal-Wallis rank sum test $(\mathrm{K})$ with d.f. $=2$. Significant differences (in bold) are considered when P values $<0.05$. In the Portaferry data, subscript letters denote significant differences revealed by pairwise Dunn tests. Mean ( \pm S.E.) values are also included to allow for easy comparison with other values reported in the literature.

\begin{tabular}{|c|c|c|c|c|c|}
\hline Location & Method & Films & Fragments & Fibres & Total \\
\hline \multirow[t]{3}{*}{ Falklands } & Bottle & $0.00(0.00-0.74)$ & $0.00(0.00-0.00)$ & $9.00(7.25-13.00)$ & $9.00(8.00-13.00)$ \\
\hline & Bongo & $0.00\left(0.00-1.34 \times 10^{-6}\right)$ & $9.23 \times 10^{-6}\left(1.42 \times 10^{-6}-2.8 \times 10^{-6}\right)$ & $8.00 \times 10^{-5}\left(2.70 \times 10^{-5}-1.8 \times 10^{-4}\right)$ & $1.04 \times 10^{-4}\left(3.26 \times 10^{-5}-2.10 \times 10^{-4}\right)$ \\
\hline & & $\mathrm{W}=16, \mathrm{P}=0.774$ & $\mathrm{~W}=30, \mathrm{P}=0.028$ & $\mathrm{~W}=78, \mathrm{P}=0.005$ & $\mathrm{~W}=78, \mathrm{P}=0.005$ \\
\hline \multirow[t]{2}{*}{$\operatorname{Mean}(S . E)$} & Bottle & $3.33( \pm 2.11)$ & 0 & $9.50( \pm 1.63)$ & $9.83( \pm 1.47)$ \\
\hline & Bongo & $6.22 \times 10^{-7}\left( \pm 3.94 \times 10^{-7}\right)$ & $1.47 \times 10^{-5}\left( \pm 6.66 \times 10^{-6}\right)$ & $1.02 \times 10^{-4}\left( \pm 3.86 \times 10^{-5}\right)$ & $1.19 \times 10^{-4}\left( \pm 4.23 \times 10^{-5}\right)$ \\
\hline \multirow[t]{3}{*}{ Plymouth } & Bottle & 0 & $0.00(0.00-0.75)$ & $2.00(1.00-2.00)$ & $2.00(1.25-3.00)$ \\
\hline & Manta & 0 & $0.00(0.00-0.00)$ & $6.43 \times 10^{-4}\left(0.00-1.20 \times 10^{-3}\right)$ & $6.4 \times 10^{-4}\left(0.00-1.24 \times 10^{-3}\right)$ \\
\hline & & N/A & $\mathrm{W}=58, \mathrm{P}=0.455$ & $\mathrm{~W}=100, \mathrm{P}<0.001$ & $\mathrm{~W}=100, \mathrm{P}<0.001$ \\
\hline \multirow{2}{*}{ Mean (S.E) } & Bottle & 0 & $3.00( \pm 1.53)$ & $2.30( \pm 5.59)$ & $2.60( \pm 5.42)$ \\
\hline & Manta & 0 & $1.16 \times 10^{-4}\left( \pm 7.76 \times 10^{-5}\right)$ & $6.67 \times 10^{-4}\left( \pm 2.09 \times 10^{-4}\right)$ & $7.83 \times 10^{-4}\left( \pm 2.66 \times 10^{-4}\right)$ \\
\hline \multirow[t]{4}{*}{ Portaferry } & Bottle & $0.00(0.00-0.00)$ & $0.00(0.00-1.00)$ & $0.00(0.00-0.50)$ & $1.00(0.00-1.00)$ \\
\hline & Coarse & $0.00(0.00-0.00)$ & $0.00\left(0.00-2.12 \times 10^{-4}\right)$ & $1.70 \times 10^{-4}\left(0.00-2.12 \times 10^{-4}\right)$ & $2.12 \times 10^{-4}\left(1.56 \times 10^{-4}-3.54 \times 10^{-4}\right)$ \\
\hline & Fine & $2.12 \times 10^{-4}\left(0.00-4.24 \times 10^{-4}\right)$ & $1.70 \times 10^{-4}\left(0.00-3.18 \times 10^{-4}\right)$ & $8.49 \times 10^{-4}\left(7.43 \times 10^{-4}-1.13 \times 10^{-3}\right)$ & $1.36 \times 10^{-3}\left(1.17 \times 10^{-3}-1.60 \times 10^{-3}\right)$ \\
\hline & & $\mathrm{K}=7.25, \mathrm{P}=0.027$ & $\mathrm{~K}=0.43, \mathrm{P}=0.810$ & $\mathrm{~K}=12.22, \mathrm{P}=0.002$ & $\mathrm{~K}=17.78, \mathrm{P}<0.001$ \\
\hline \multirow[t]{3}{*}{ Mean (S.E) } & Bottle & ${ }_{a} O$ & $7.14 \pm 4.21$ & ${ }_{a} 1.14( \pm 0.34)$ & ${ }_{a} 1.29( \pm 8.08)$ \\
\hline & Coarse & ${ }_{a} 2.02 \times 10^{-5}\left( \pm 2.02 \times 10^{-5}\right)$ & $1.52 \times 10^{-4}\left( \pm 8.92 \times 10^{-5}\right)$ & ${ }_{b} 1.25 \times 10^{-4}\left( \pm 4.60 \times 10^{-5}\right)$ & ${ }_{b} 2.97 \times 10^{-4}\left( \pm 1.04 \times 10^{-4}\right)$ \\
\hline & Fine & ${ }_{b} 2.73 \times 10^{-4}\left( \pm 1.29 \times 10^{-4}\right)$ & $1.96 \times 10^{-4}\left( \pm 8.52 \times 10^{-5}\right)$ & ${ }_{a} 9.38 \times 10^{-4}\left( \pm 1.41 \times 10^{-3}\right)$ & ${ }_{c} 1.41 \times 10^{-3}\left( \pm 1.58 \times 10^{-4}\right)$ \\
\hline
\end{tabular}


Table 2. Average ( \pm S.E) number $\mathrm{L}^{-1}$ of microplastic films, fragments and fibres determined bulk one litre samples using glass bottles $(\mathrm{n}=5)$.

531

\begin{tabular}{llllll}
\hline Location & Site & Films & Fragments & Fibres & Total \\
\hline Ascension Island & Long beach & - & - & $0.4( \pm 0.24)$ & $0.4( \pm 0.24)$ \\
& Pan Am A & $0.8( \pm 0.58)$ & - & $7.2( \pm 2.75)$ & $8.0( \pm 2.51)$ \\
& Pan Am B & - & - & $3.2( \pm 1.32)$ & $3.2( \pm 1.32)$ \\
& Boatswain Bird Island & $1.0( \pm 0.55)$ & - & $6.8( \pm 3.46)$ & $7.8( \pm 3.89)$ \\
& North East Bay & $1.2( \pm 0.73)$ & - & $2.8( \pm 0.86)$ & $4.0( \pm 1.30)$ \\
& English Bay & $0.4( \pm 0.40)$ & - & $3.8( \pm 1.68)$ & $4.2( \pm 2.06)$ \\
& & & & \\
Falklands Islands & Bleaker Island & - & - & $3.6( \pm 0.81)$ & $3.6( \pm 0.81)$ \\
& New Haven & - & - & $5.6( \pm 2.78)$ & $5.6( \pm 2.78)$ \\
& Bertha's Beach & - & - & $2.8( \pm 1.11)$ & $2.8( \pm 1.11)$ \\
& Fitzroy & - & - & $3.6( \pm 0.67)$ & $3.6( \pm 0.67)$ \\
& Goose Green & - & - & $4.6( \pm 1.91)$ & $4.6( \pm 1.91)$ \\
& Elephant Beach & $0.8( \pm 0.37)$ & - & $7.2( \pm 2.27)$ & $8.0( \pm 2.41)$ \\
& San Carlos & - & - & $8.8( \pm 0.80)$ & $8.8( \pm 0.80)$ \\
& Teale Inlet & - & - & $5.8( \pm 1.65)$ & $5.8( \pm 1.65)$ \\
& Green Patch & - & - & $7.8( \pm 1.16)$ & $7.8( \pm 1.16)$ \\
& Stanley Harbour & $0.2( \pm 0.20)$ & - & $2.8( \pm 0.49)$ & $3.2( \pm 0.66)$ \\
Cape Dolphin & $0.2( \pm 0.20)$ & $0.8( \pm 0.2)$ & $7.4( \pm 1.07)$ & $8.4( \pm 1.21)$ \\
& Port William & $0.3( \pm 0.21)$ & - & $9.5( \pm 1.63)$ & $9.8( \pm 1.47)$ \\
\hline
\end{tabular}

